\title{
APPLICATION OF GIS IN ASSESSING NATURAL CONDITIONS FOR THE DEVELOPMENT OF RASPBERRY GROWING AT THE TERRITORY OF THE MUNICIPALITY OF ŠTRPCE
}

\author{
Uroš Durlević', Bogdan Mihailović, ${ }^{1}$ Vladimir Ćurić \\ Received: February 22, 2018 | Accepted: May 11, 2018
}

\begin{abstract}
The paper presents the analysis of natural conditions for the development of the agricultural branch - raspberry growing in the municipality of Štrpce. The following analyses were carried out using GIS technology: the analysis of pedological cover, terrain aspect and slope, hypsometric conditions, precipitation and land use methods. The paper also presents the materials and methods for obtaining the final evaluation of the conditions and assessing the natural characteristics for the territory of Štrpce. By cabinet work, elimination method, and valorisation method through software packages, the analysis and interpretation of natural characteristics was carried out on all maps individually. In the geographic information systems, one of the most important materials in research is the database, i.e. its availability and scope. The final version of the work is formed by processing all natural conditions through GIS. The final result of the work and research is a synthetic map of the benefits for raspberry growing in the area of Štrpce, with pronounced areas suitable for the development of raspberry growing. The main reason for determining these locations is the uncertain economic stability and insufficiently informed local population due to the unfavourable political situation in the Autonomous Province of Kosovo and Metohija.
\end{abstract}

Keywords: GIS, raspberry, agriculture, natural conditions, Štrpce.

\section{INTRODUCTION}

The municipality of Štrpce is located in the southern part of AP Kosovo and Metohija, with a land area of around $248 \mathrm{~km}^{2}$. Due to the high unemployment rate and uncertain future, the local population is forced to turn to agricultural branches: farming and livestock breeding. For this reason, it is highly important to turn to the potentials

Department of Geospatial and environmental science, Faculty of Geography, University of Belgrade, Studentski trg 3/III, 11000 Belgrade, Serbia, contact: durlevicuros@gmail.com 
of agricultural production, and the terrain analysis with the help of GIS applications enables a quick and efficient understanding of the natural conditions suitable for (in this case) raspberry growing. For the needs of agriculture, geographic information systems are extremely useful in mapping and projecting current and future fluctuations in precipitation, temperature, crop fertility and much more (Borneman, 2014). The considerable significance of GIS is reflected in the fact that a large part of the work can be done by cabinet work, and that highly precise data about locations and natural conditions that apply to a given space can be obtained in combination with field research. The development of modern information technologies has formed a system for spatial data management and their integration into a unique spatial information system (Milanović, Filipović, 2017, 125). The advantage of the applied methodology in the GIS environment is that new alternatives, but also different criteria and sub-criteria, can be added in a simple way (Stojković et al., 2015, 62). What distinguishes GIS from other information systems is that every piece of information in the database has its spatial representation (Seferović, Stankov, 2009, 118). Raspberry is a popular agricultural crop in the southwestern part of Serbia, but, generally, its potential is still poorly developed in other parts of the country. Intensive raspberry production implies regular and abundant yield and high quality of fruit (Petrović, Leposavić, 2016, 31). Agroecological conditions for raspberry growing can be determined using GIS applications. In the study of conditions for the area of Štrpce, the following characteristics were taken: pedology (soil types), terrain aspect and slope, altitude, precipitation and land use method.

Soil type plays one of the most important roles for proper raspberry cultivation. The great yield of this fruit is expected on Cambisols, Cambisols slightly turned into podzols, and alluvial soil, due to biochemical characteristics of the soil (PH value, the percentage of humus, etc.). The soil must be deep enough, not too moist or too dry. The level of groundwater can influence the development of raspberries, so it is recommended to use ground where groundwater is not shallower than $90 \mathrm{~cm}$.

Aspect (terrain exposure) is an important and locally variable factor. Depending on the percentage of moisture, humus in the soil, and altitude, suitable aspect is variable. In addition to the aspect, an equally important natural condition is the slope of the terrain. A slight slope (about $5^{\circ}$ ) is best suited for raspberry. For the conditions of the Republic of Serbia, varieties of raspberry which yield good results with 13 to 16 daylight hours are recommended (Petrović, Leposavić, 2016, 33).

Hypsometry (altitude) is a natural factor that significantly affects the climatic conditions in which raspberry is to be grown - temperature decreases and precipitation increases with increasing altitude, so the optimal hypsometric conditions for raspberry growing are terrains at $400-800 \mathrm{~m}$.

Precipitation is one of the most important climatic characteristics affecting the fertility of the soil. If there are dry periods, the soil is not sufficiently rich in water, and the fruit shrivels. On the other hand, too much precipitation does not positively affect raspberry; due to higher moisture content, the plant becomes more susceptible to various diseases, so the value of $800-1000 \mathrm{~mm}$ is taken as the optimal amount of precipitation, preferably evenly distributed throughout the year. Intensive and highly productive raspberry production without irrigation is possible only in areas with over $800 \mathrm{~mm}$ of pre- 
cipitation per year, more than $50 \%$ of which is evenly distributed throughout the growing period, normally with the optimal application of agro-technical and other measures (Petrović, Leposavić, 2016, 36). Among other climatic characteristics, air and wind also affect raspberry growing. Moderate-continental climate and a large number of sunny days, but not too warm, are favourable for raspberry. Frost adversely affects plant development but it does not cause much damage if it occurs during the "winter rest" (which lasts from November to April in our region). Wind can affect raspberries both positively and negatively, depending on its speed. The gentle wind (breeze) favours growing as it refreshes the air around the plant, but also slows down the development of fungal diseases. Strong winds can damage the shoots, impede the work of bees and pollination, but also dry out the air and the land on which raspberries are cultivated (Petrović, Leposavić, 2016, 37).

\section{MATERIALS AND METHODS}

GIS software packages GeoMedia Professional and Idrisi were used for determining natural conditions for raspberry growing in Štrpce. Some GIS software programs are traditionally more focused on supporting work with raster while others are more focused on supporting work with vector-based geospatial objects, such as the GeoMedia Professional software (Stojković, 2015, 15). The method of work is cabinet work and provides efficient and quickly accessible data on parameters serving to assess natural conditions and form analytical and synthetic maps. For the purposes of studying and assessing natural conditions, six analytical and one synthetic map were used, which synthetic map at the end represents a set of all individual maps.

The pedological map was obtained by digitizing the soil from the 1: 50.000 pedological maps, digitized soils were later classified into the corresponding types to which they belong. On the basis of the results obtained by the classification, we distinguished among 5 types of land for the area of Štrpce.

For the purposes of mapping the land use methods, the Corine Land Cover program was used to obtain the classes of land use methods. In the case of the municipality of Štrpce, 12 classes were distinguished.

The hypsometric map was obtained from raster DEM 100 (digital elevation model). The program reclassified the elevation zones with $300 \mathrm{~m}$ intervals. The map shows 8 different elevation zones in the range of 400-2800 m.

The terrain aspect map the shows the exposure of terrain in relation to a particular direction. In this case, the methods identical to those of the hypsometric map were used, and the aspect was reclassified from DEM. Depending on the suitability of the conditions for raspberry growing, aspect plays an important role in determining a suitable space for the development of this crop.

The map of terrain slope angles was also made by the DEM principle, and the classification was performed according to the degree of terrain inclination. For the area of Strpce, the values on this map are classified into 5 classes, in the total interval of $0-50^{\circ}$. 
The amount of precipitation for the territory of the municipality of Štrpce was obtained on the basis of the formula for calculation of precipitation (Živković, 2009):

$$
P=551.7 \cdot \ln (D E M)-2808 P=551.7 \cdot \ln (D E M)-2808,
$$

where:

$P$ - total precipitation, DEM (H) - digital elevation model, ln- natural logarithm

In this map as well, a classification was made according to the amount of precipitation in a given area. After calculating values by the formula in the Image calculator, the values for the municipality of Štrpce vary in the range of $600-1600 \mathrm{~mm}$.

As the final result of the analysis of 6 maps, a synthetic map is created representing a combination of values from all individual maps. This map shows complete natural conditions for the development of raspberry growing in the area of Štrpce. The assessment of the conditions is determined by the following procedure:

$$
S_{k}=\frac{\sum_{i=1}^{n} S_{i}}{n}=\frac{S_{1}+S_{2}+S_{3}+S_{4}+S_{5}+S_{6}}{6}
$$

where:

$S_{k}$ - synthesis map, $S_{i}$ - individual maps, $n$ - number of maps

The synthetic map is formed by the addition of all individual maps and then division with the number of individual maps used in the analysis.

\section{RESULTS AND DISCUSSION}

The soil is the basic and one of the main reasons for distributing raspberry growing. Soils have properties depending on the conditions of their formation, the evolutionary stage, and the influence of anthropogenic factors (Lješević, 2003, 45). Due to anthropogenic effects, not only the structure and content of nutrients, but also the system of the living world is disturbed, leading to reduced ability of soil self-purification (Milošević et al., 2014, 2). One of the more important soil characteristics is water retention. Soil structure and texture are properties determining the retention and infiltration of water (Novković, Dragićević, 2015). Soils in Štrpce include rendzinas, rankers, lithosols, calcocambisols, brown shallow soils and alluvial-deluvial soils. Alluvial-deluvial soil is taken as the most suitable soil for the development of raspberry growing in Štrpce due to its biochemical characteristics. Alluvial soils are formed along the watercourses, in the coastal zone of floodplain soils where the flood waters sort and deposit coarser sand materials (Miljković, 1996, 223). Much of this land stretches along the coastal parts of the Lepenac River. 

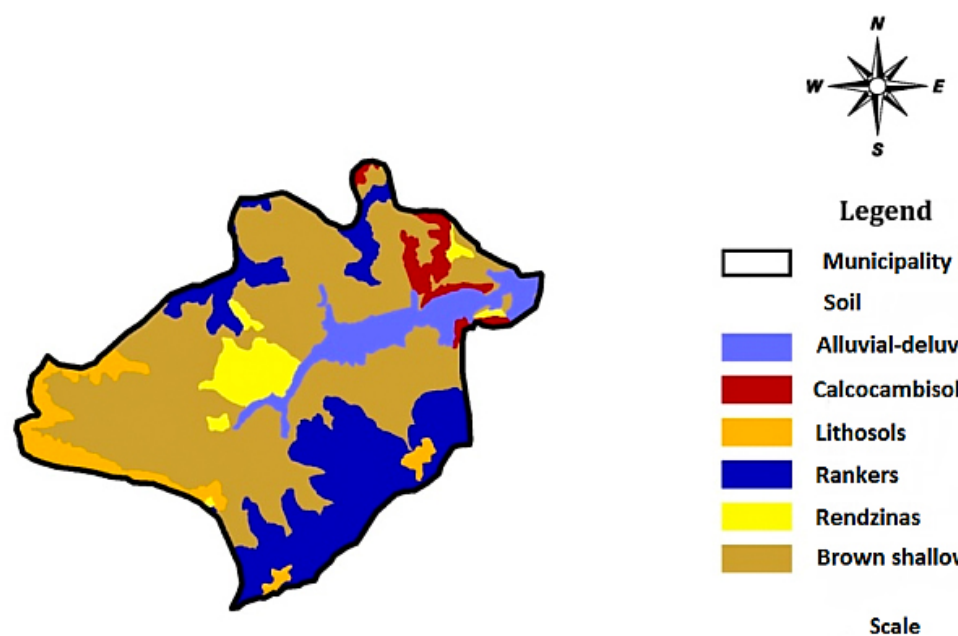

\section{Legend}

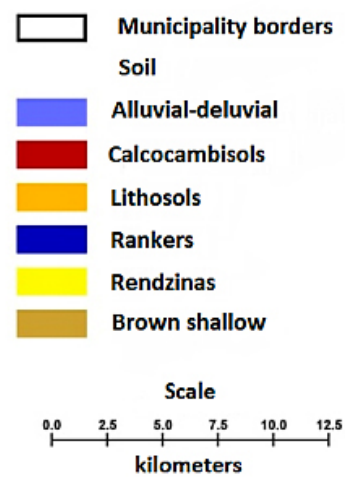

Figure 1. Pedological map

The method of land use depends on the natural and anthropogenic impact. Forestry vegetation (coniferous, deciduous and mixed) is mostly represented in the area of the municipality of Štrpce. The entire territory of the municipality of Štrpce is located within the Shar Mountain National Park, so the area of the municipality is divided by protection zones. The southern part of the municipality belongs to I degree of protection. All activities in this zone, apart from scientific research, controlled education, preservation and improvement of the existing state of ecosystems, are forbidden (Đurđić, 2015, 121). The most favourable conditions for the development of raspberry growing are non-irri-

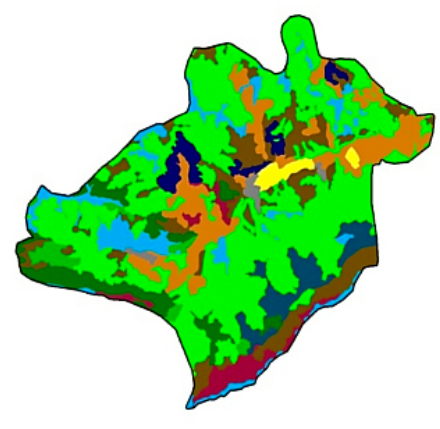

Legend
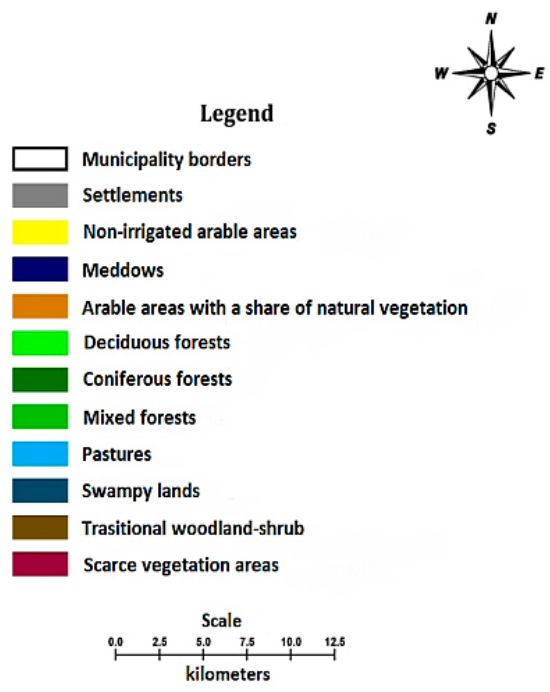

Figure 2. Land use methods map 
gated arable areas. Many parts of Štrpce feature arable areas with a trace of natural vegetation. Meadows are replaced by bushy vegetation with the increasing altitude, and pastures, swampy lands, and scarce vegetation areas dominate the region under the peaks of the Sharr Mountain.

Altitude is the dominant factor in determining the development of raspberry growing as it directly affects the air temperature and the amount of precipitation that reaches a given area. In the territory of the municipality of Štrpce, the majority of the population is concentrated in settlements at an altitude of $700-1300 \mathrm{~m}$. The conditions that would most suit raspberries are the intervals of $400-800 \mathrm{~m}$, so in this case as well, the Lepenica valley gives the most favourable conditions, while the most severe conditions spread in the south of the municipality.

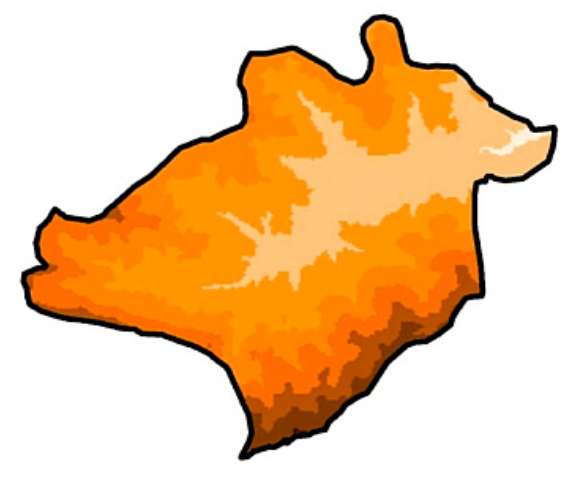

Aspect (exposure) of terrain is in the major part of the municipality fully suitable for raspberries. The shady (northern) sides are mostly suitable for raspberries because of the higher soil moisture and the higher percentage of humus compared to the western, eastern and southern parts. However, at altitudes higher than $800 \mathrm{~m}$, priority should be given to southern exposures (Veličković, 2007, 13).

Terrain slope affects both the development of the plant itself and the surface layer of the soil that supplies the plant. Terrain slope determines the possibility of using the soil, as well as the intensity of natural processes that occur on the surface (Novković et al., 2014, 87). The most suitable angle of inclination for raspberry growing is around $5^{\circ}$, which can be found in Štrpce in the coastal parts, on alluvial-deluvial soil. Due to greater inclination, erosion may occur, which would significantly reduce the fertility of raspberries. The maximum terrain slope in the municipality is $44.22^{\circ}$. 

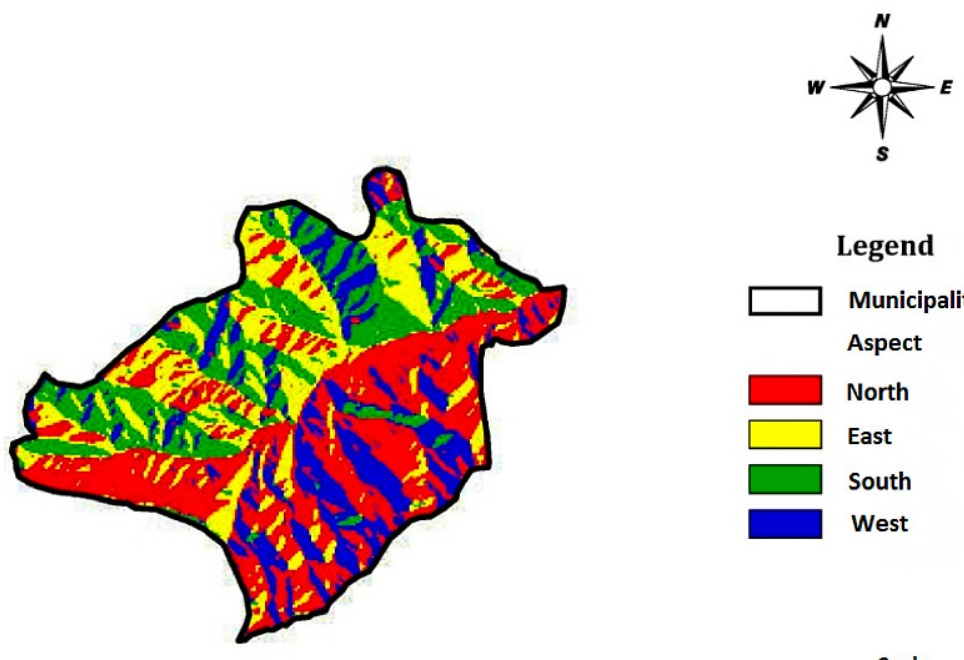

\section{Legend}

Municipality borders

Aspect

North

East

South

West

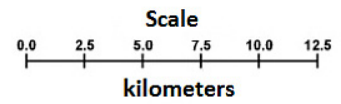

Figure 4. Terrain aspect map

Precipitation is one of the most important climatic elements that influence the development of complete agriculture in the world. For most crops, a certain annual amount of precipitation is required to make the plant healthier and make the fruit grow larger. The pluviometric regime in Štrpce varies mainly due to the significant relief segmentation (differences in altitude), so the values range from 600 to $1600 \mathrm{~mm}$.

The area near rivers and streams would be the most suitable place for raspberry growing with an annual precipitation of $800-1000 \mathrm{~mm}$. The altitude and therefore the
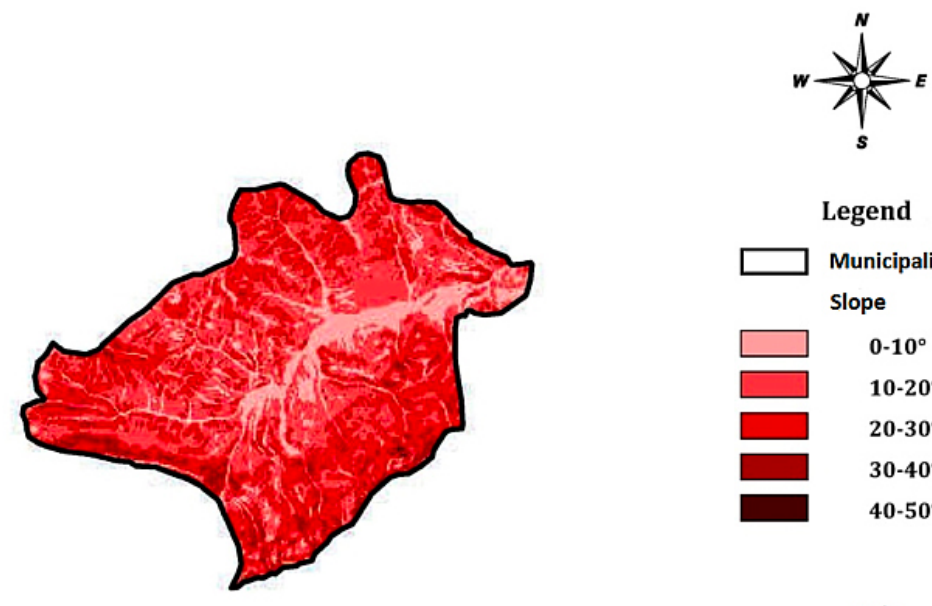

Legend

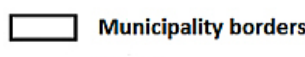

Slope
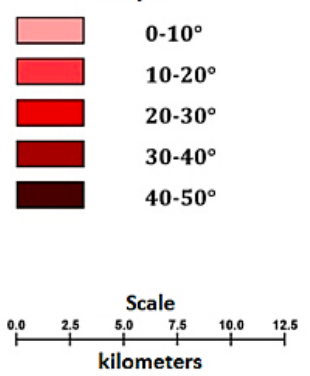

Figure 5. Terrain slope map 

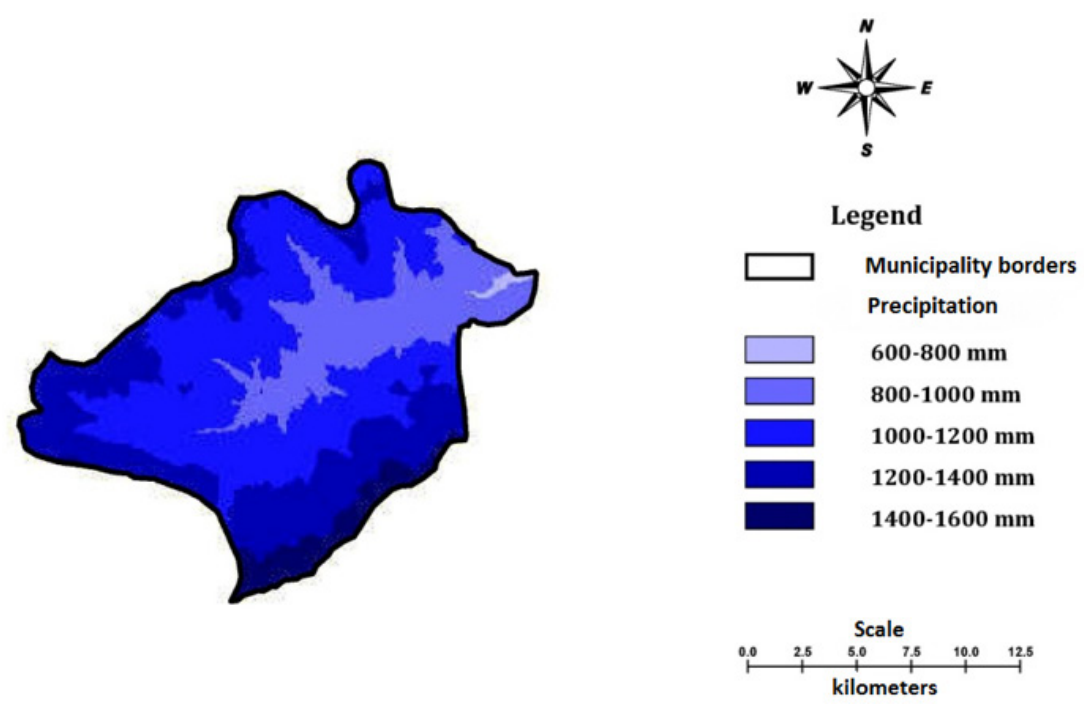

Figure 6. Precipitation map

amount of precipitation increase with moving from the centre of the municipality and approaching the periphery, so in those regions raspberries grow to a slightly weaker extent.

When all the conditions are considered and a synthetic map is formed, it can be noticed that the most favourable conditions for raspberry growing are found in the central part of the municipality in the area of about $6.9 \mathrm{~km} 2$. This area covers the area around the Lepenac River, which, according to its pedological, geomorphological and climatic characteristics, is most suitable for growing raspberries.
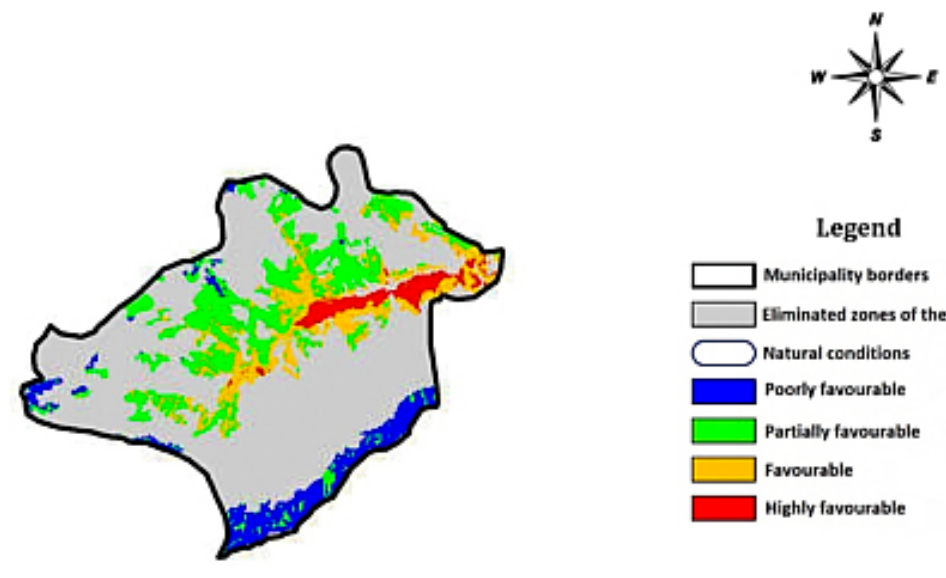

Legend
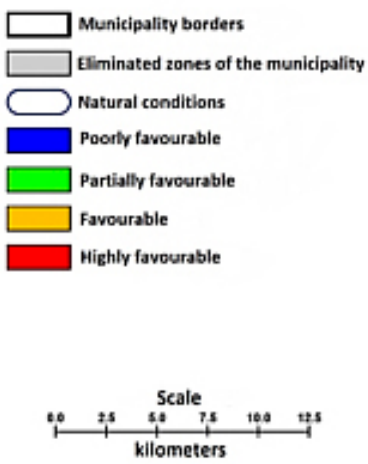

Figure 7. Synthetic map of benefits 
Table 1. Assessment of natural conditions for raspberry growing

\begin{tabular}{|l|c|c|}
\hline Natural conditions & Share in the territory (\%) & Assessment \\
\hline Highly favourable & 2.78 & 5 \\
\hline Favourable & 10.1 & 4 \\
\hline Partially favourable & 14.9 & 3 \\
\hline Poorly favourable & 6.87 & 2 \\
\hline Eliminated zones & 65.35 & 1 \\
\hline
\end{tabular}

\section{CONCLUSION}

Based on the explored natural conditions using GIS technology, the area of Štrpce municipality can be comprehensively assessed against the benefits for growing raspberries as an agricultural activity from which local population (due to economic uncertainty and difficult living conditions) could provide socio-economic stability for a certain period of time.

A large part of the municipality includes the so-called eliminated zones of the municipality, for two reasons: in the southern part of the municipality there are protected areas of the National Park belonging to I degree of protection (forests and meadows) and this part must not be disturbed, and the second reason is the very rural villages in which agricultural production is not efficient and recommended. Considering the poorly favourable conditions (mostly found on the slopes of the Shar Mountain) and the eliminated zones, the rest of the territory of Štrpce (about $69 \mathrm{~km} 2$ ) has relatively favourable conditions for raspberry cultivation. It is necessary to increase investments, provide financial, scientific and technical support in the implementation and intensification of the development of raspberry growing in the territory of the municipality of Štrpce, but also in all the other parts of the Republic of Serbia where the potential for growth of the raspberry industry is significant.

\section{REFERENCES}

Veličković, N. (2007): Malina, praktični priručnik - prvo izdanje. Bijelo Polje: Pegaz. Borneman E. (2014). Use of GIS in Agriculture, GIS Lounge.

Đurđić S. (2015). Zaštita prirode. Univerzitet u Beogradu, Geografski fakultet.

Živković N. (2009). Prosečni godišnji i sezonski oticaji reka u Srbiji. Univerzitet u Beogradu, Geografski fakultet.

Lješević M. (2003). Geografija zemljišta. Nikšić: Institut za geografiju Filozofskog fakulteta.

Milanović M., Filipović D. (2017). Informacioni sistemi u planiranju i zaštiti prostora. Univerzitet u Beogradu, Geografski fakultet. 
Milošević D., Nađ I., Stojanović V. (2014). Zemljišta u gradovima: Stanje, problemi i tehnike remedijacije. Novi Sad: Zbornik radova Departmana za geografiju, turizam i hotelijerstvo, 43-1, 2.

Miljković N.S. (1996). Osnovi pedologije. Univerzitet u Novom Sadu, Prirodnomatematički fakultet, Institut za geografiju.

Novković I., Dragićević S. (2015). Ugroženost opštine Ljig bujičnim poplavama. Kopaonik: Četvrti srpski kongres geografa - aktuelnosti i izazovi geografske nauke i prakse. Univerzitet u Beogradu, Geografski fakultet, Srpsko geografsko društvo.

Novković I., Đurković M., Stankov S., Milošević B. (2014). Geoecological evaluation of the National park "Djerdap" (Serbia) for tourism and recreation. The Environment Journal of Environmental Sciences, Volume 2, No.2, 87. University of Belgrade - Faculty of geography.

Pedološka karta SFRJ, 1:50.000 - Listovi: Kačanik 1,2,3,4 (1971-1974). Beograd: Vojnogeografski institut.

Petrović S., Leposavić, A. (2016). Malina, nove tehnologije zaštite, gajenja i prerade. Čačak: Naučno voćarsko društvo Srbije.

Seferović S., Stankov U. (2009). Opšta i specifična upotreba geografskih informacionih sistema u turizmu. Novi Sad: Zbornik radova Departmana za geografiju, turizam i hotelijerstvo, 38, 118.

Stojković S. (2015). Uvod u GIS - praktikum. Univerzitet u Beogradu, Geografski fakultet.

Stojković S., Đurđić S., Anđelković G. (2015). Primena višekriterijumske analize i GIS-a u razvoju ekoturizma (studija slučaja: Podunavlje, Srbija). Beograd: Glasnik Srpskog geografskog društva, 62.

Corine (Coordination of information on the environment) Land Cover. European Environment Agency (EEA) - Geoprostorna baza podataka o načinu korišćenja zemljišta izdata od strane Evropske Agencije za zaštitu životne sredine. 